\title{
THE INTERNATIONAL ADJUDICATION OF MEGA-POLITICS
}

\author{
KAREN J. AlteR* AND MIKAEL RASK MADSEN**
}

I

\section{INTRODUCTION}

What happens when international courts (ICs) are asked to adjudicate highly divisive or polarizing social or political issues? What are the consequences for the courts themselves, for the law in question, and for politics and society when highly contentious issues are brought before the international bar? ICs can become involved in polarizing domestic issues that are governed by international law, such as the rights of migrants, minorities, or religious groups. And they can become embroiled in high-stakes international disputes, such as conflicts over territory, over the use of military or economic coercion, or disagreements about property and money owed.

This special issue investigates these high stakes cases under the heading of the international adjudication of mega-politics. Ran Hirschl coined the term "megapolitics" to describe "matters of outright and utmost political significance that often divide whole polities." ${ }^{1}$ The definitional focus on polities distinguishes mega-politics from the international relations category of high politics, the latter being typically seen as national-interest and security related issues of concern to governments, political leaders, and militaries, but not necessarily the polity more broadly. Whereas Hirschl saw "mega-politics" cases as those where courts, both national and international, spoke to fundamental questions that defined the identity of a polity, we broaden the concept. In our definition, judicialized megapolitics applies whenever ICs are adjudicating legal issues that divide domestic societies or inter-state relations such that one would anticipate that, whatever the outcome, important and sizable social or political groups will end up greatly upset. We include issues not only related to the identity of a polity, as in Hirschl's definition, but also other social, economic, and political conflicts that create cleavages at the national and international levels across or between societies.

Copyright (C) 2021 by Karen J. Alter \& Mikael Rask Madsen.

This Article is also available online at http://lcp.law.duke.edu/.

* Karen J. Alter is a Norman Dwight Harris Professor of International Relations and Professor of Political Science and Law at Northwestern University. She is also a permanent visiting professor at the iCourts Center for Excellence and a University of Copenhagen Faculty of Law.

** Mikael Rask Madsen is a Professor of Law at the University of Copenhagen and the Director of iCourts Center for Excellence for International Courts at the Danish National Research Foundation.

1. Ran Hirschl, The Judicialization of Mega-Politics and the Rise of Political Courts, 11 ANN. REV. POL. SCI. 93, 93 (2008) [hereinafter Hirschl, Judicialization of Mega-Politics]. 
International adjudicators have long been asked to decide politically sensitive and controversial issues, some of which might be defined as mega-political. Historically, international adjudicators focused mostly on trans-border disputes that, while sometimes contentious, for the most part did not divide domestic populations. $^{2}$ Moreover, the requirement of case-specific consent to litigation ensured that the litigating governments were ready to accept the international judicial determination.

Increasingly, ICs are monitoring states' behind the border adherence to international commitments such as human rights treaties, laws of war, nondiscrimination, rule of law, and trade rules. ${ }^{3}$ These legal domains inherently bring ICs more deeply into domestic social and political matters. It is also more common today for ICs to have or claim compulsory jurisdiction for the case being adjudicated, so government support for the case's outcome cannot be assumed. ${ }^{4}$ The rise of nationalist sentiments and forms of political populism adds an extra layer of controversy, leading nationalist politicians to invoke the supremacy of democratic deliberation or sovereignty as a basis to reject even well-reasoned rulings involving clear violations of international law. These developments mean that international adjudication is both internationally and domestically sensitive.

We are interested first and foremost in what happens to ICs when they become embroiled in mega-politics. At first glance, any IC involvement in megapolitics would seemingly be politically risky precisely because IC rulings are likely to be contested and perhaps ignored. Since flagrant disregard for salient IC rulings can undermine IC authority and diminish state support for ICs, ICs might suffer from engaging in such cases. Yet these dangers do not always arise. Studies of both domestic and international judicial involvement in highly contested cases suggest that courts are sometimes empowered by high stakes cases because they are seen as siding with the people, the rule of law, democratic will, or with powerful local allies. One question explored in this project is the range of institutional consequences for ICs for adjudicating mega-political disputes. These consequences include both positive and negative effects on IC authority, ${ }^{5}$ and the domestic and international institutional transformations that mega-political cases

2. See generally Tom Bingham, The Alabama Claims Arbitration, 54 INT'L \& COMP. L.Q. 1 (2005) (stating that in the Alabama Claims the United States insisted on British compensation for intervention on the side of the Confederacy during the U.S. civil war); Manley O. Hudson, The Corfu Channel Case: Significance of First Ruling by Present Court, 34 A.B.A. J. 467 (1948) (describing the first case adjudicated by the International Court of Justice, which involved Albania's mining of the Corfu straits with Greece that caused damage to British warships intervening in the Greek civil war).

3. Karen J. Alter, The NeW Terrain of InTERnational LaW: Courts, Politics, Rights 120-24 (2014) [hereinafter ALTER, THE NEW TERRAIN OF INTERNATIONAL LAW].

4. See generally Cesare Romano, The Shift from the Consensual to the Compulsory Paradigm in International Adjudication: Elements for a Theory of Consent, 39 N.Y.U. J. INT’L L. \& POL. 791 (2007); Mary Ellen O'Connell \& Lenore VanderZee, The History of International Adjudication, OXFORD HANDBOOK ON INTERNATIONAL ADJUDICATION 40 (2014).

5. See generally Karen J. Alter, Laurence R. Helfer \& Mikael Rask Madsen, INTERNATIONAL COURT AUTHORITY (2018) [hereinafter ALTER ET AL., INTERNATIONAL COURT AUTHORITY]. 
may engender.

Secondly, as a comparative project, we are also interested in understanding variation in these different outcomes, as well as the various strategies and ways that ICs and stakeholders engage with fraught mega-political disputes. As a collective endeavor, the contributions to this special issue examine a host of empirical examples of the adjudication of mega-political issues across ICs and subject-areas as well as different international contexts.

Thirdly, we are interested in what happens to the mega-political conflict itself; that is, the effects of the adjudication of mega-politics on the law in question, as well as on the social and political stakes involved in the issue. Simply put, does international adjudication solve, mediate, exacerbate, or merely continue the divisions in politics and societies? If the international intervention makes the situation worse, there may be no winners and the IC may lose legitimacy, support and, ultimately, authority. Alternatively, transferring a dispute out of domestic or regional political arena could help local actors accept an outcome they do not like. Our inquiry draws insight from short-term and long-term perspectives on the consequences of the international adjudication of mega-politics to explore the larger consequences of international judicial involvement in highly contested issue-areas.

Fourthly, we are interested in whether ICs adjudicating mega-politics foments backlash against ICs. Most literature on backlash against ICs focuses on how particular IC rulings catalyze or become the focal object of backlash politics, or they study how these rulings trigger pushback or backlash. ${ }^{6}$ By contrast, this project examines cases that are a priori likely to generate pushback. ${ }^{7}$ In methodological terms, the special issue is focused on the most likely cases for backlash against ICs. As Part II will explain, Hirschl's definition of judicialized mega-politics pertains to the issue being adjudicated, not the ruling itself or the politicization of a ruling after the fact. This special issue sees the combination of a highly politicized subject-matter and international judicial intervention as increasing the probability of an adverse political response, which is why mega-

6. There is a growing literature on these matters. See generally Mikael Rask Madsen, Pola Cebulak \& Micha Wiebusch, Backlash against International Courts: Explaining the Forms and Patterns of Resistance to International Courts, 14 INT'L J.L. CONTEXT (2018) [hereinafter Madsen et al., Backlash Against International Courts]; Karen J. Alter, The European Legal System and Domestic Policy: Spillover or Backlash, 54 INT'L ORG. 489 (2000); Karen J. Alter, James T. Gathii \& Laurence R. Helfer, Backlash Against International Courts in West, East and Southern Africa: Causes and Consequences, 27 EUR. J. INT'L LAW 293 (2016) [hereinafter Alter et al., Backlash Against International Courts in West, East and Southern Africa]; Erik Voeten, Populism and Backlashes Against International Courts, 18 PERSP. ON POL. 407 (2020) [hereinafter Voeten, Populism and Backlashes Against International Courts]; Wayne Sandholtz, Yining Bei \& Kayla Caldwell, Backlash and International Human Rights Courts, CONTRACTING HUMAN RIGHTS (2018). Each of these sources characterizes political backlash against IC decisions.

7. See generally Mikael Rask Madsen, Resistance to the European Court of Human Rights: The Institutional and Sociological Consequences of Principled Resistance, in PRINCIPLED RESISTANCE TO ECTHR JUdGMENTS - A NEW PARADIGM? (Marten Breuer ed., 2019) (showing that even minor political issues and disagreements can lead to greater principled problems and backlash, if - for a number of contextual reasons - politicians decide to escalate their conflicts with ICs). 
politics cases are the most likely cases for backlash. We seek to better understand why only sometimes adjudicating controversial cases and disappointing powerful actors foments backlash.

This introductory Article to the special issue focuses on defining and identifying the contexts that give rise to the international adjudication of megapolitics, and it theorizes about the strategies and challenges of ICs that are called upon to adjudicate mega-political disputes. The contributors to the special issue then address what happens to a range of mega-political disputes. Finally, the special issue's conclusion returns to the issue of how international adjudication impacts mega-political disputes.

The remainder of this article is structured as follows. Part II outlines and defines the key tenets of the adapted concept of judicialized mega-politics. Part III identifies structural contexts that give rise to mega-politics, identifying three categories of cases most likely to engender mega-politics: 1) inter-state disputes; 2) social cleavage disputes; and 3) sovereignty-based disputes. Part IV discusses the particularities and consequences of embroiling international adjudicators in these highly contentious legal-political issues.

There are always risks when courts intervene in issues of high salience and political significance, especially if a ruling goes against the wishes of powerful governments. Given that ICs are likely to be less well known by local populations, one might expect their legitimacy and authority to be even more fragile compared to their domestic counterparts. ${ }^{8}$ This introductory Article discusses the variable and fragile authority of ICs in general, and in light of the current nationalist populist political moment and the particular challenges it presents. ${ }^{9}$ Overall, this Article explains why the general phenomenon of ICs engaging mega-political disputes is neither new nor likely to disappear. ${ }^{10}$ Part $\mathrm{V}$ previews the contributions to the special issue. The special issue's conclusion draws on the contributions to this special issue, returning to the question of the consequences of adjudicating mega-politics cases for the particular issue or conflict and for ICs, on the strategies ICs employ to successfully minimize political pushback, and on the relationship between mega-politics and backlash against ICs and

8. See James Gibson \& Gregory Caldeira, The Legitimacy of Transnational Legal Institutions: Compliance, Support, and the European Court of Justice, 39 AM. J. POL. SCI. 459, 459 (1995) (investigating the idea that an IC's legitimacy is more fragile compared to its domestic counterparts); see also James L. Gibson, Gregory A. Caldeira \& Vanessa A. Baird, On the Legitimacy of National High Courts, 92 AM. POL. SCI. REV. 343 (1998) (further investigating the weak legitimacy of ICs). But see Karen J. Alter, Delegation to International Courts and the Limits of Recontracting Power, DELEGATION AND AGENCY IN INTERNATIONAL ORGANIZATIONS (Darren Hawkins et al. eds. 2006) (showing that retaliation against an IC can be challenging because changing legislation, court mandates, and budgets may require building international support, and because governments may be unable to retaliate against judges themselves).

9. See Alter ET AL, supra note 5, at 25-27, 452-59 (explaining the challenges of building IC authority and the fragility of this authority).

10. See generally, Karen J. Alter, The High Water Mark of International Judicialization?, iCourts Working Paper Series, No. 250, in BY PEACEFul MEANS: A TRIBUTE TO DAVID D. CARON (forthcoming 2022) [hereinafter Alter, The High Water Mark of International Judicialization?]. 
international law more generally. Circling back to these questions leads to disagreement with Ran Hirschl's argument about why courts should not become involved in adjudicating mega-politics issues.

II

\section{AdJudicating Mega-Politics: Definitional Questions}

This Part focuses on what defines a legal dispute as being mega-political. The category of mega-politics was first introduced by Hirschl in his study of juristocracy, where he critically analyzed contexts in which elites have used higher courts to maintain their power and cement their political agendas. ${ }^{11}$ In his analysis, mega-political questions appear as a sub-category of political and social issues related to fundamental questions of national identity:

"In recent years, the judicialization of politics has expanded beyond rights issues or transnational cooperation to encompass what we may term "mega-politics"-matters of outright and utmost political significance that often define and divide whole polities. These range from electoral outcomes and corroboration of regime change to matters of war and peace, foundational collective identity questions, and nation-building processes pertaining to the very nature and definition of the body politic. Examples include the fate of the American presidency, the war in Chechnya, the near-constant political turmoil in Pakistan, multicultural citizenship in Western Europe, the place of Germany in the EU, quandaries of transitional justice from the postcommunist world to postauthoritarian Latin America to postapartheid South Africa, the status of indigenous populations in Australia and New Zealand."12

We take some key elements from Hirschl's definition but revise them for our empirical context and analytical purposes. First and foremost, we agree that mega-politics is associated with the issue in dispute, not a court ruling itself or the politicization of a legal controversy. Important to the proposed definition of mega-politics is whether an issue already divides or is vocally controversial in significant segments of society. In focusing on IC adjudication of mega-politics, it is not important whether the preexisting divisions are longstanding or fairly recent, so long as the fraught social nature of the subject matter at stake is apparent, with partisans mobilized on both sides. Contemporary nationalist populism may increase the prevalence of mega-politics because populist leaders often polarize populations, vilify elite institutions (especially international ones), and attack the rule of law, but the mega-politics category is larger than such populism-inspired challenges. ${ }^{13}$ Our definition also differs from most of the

11. RAN HIRSCHL, TOWARDS JURISTOCRACY: THE ORIGINS AND CONSEQUENCES OF THE NEW CONSTITUTIONALISM 171-72 (2004) [hereinafter HIRSCHL, TOWARDS JURISTOCRACY] (noting that in nations such as Canada, Israel, New Zealand, and South Africa, "national high courts .... are strongly inclined to rule in accordance with national metanarratives and the interests and expectations of ruling elites.").

12. Hirschl, The Judicialization of Mega-Politics, supra note 1, at 984.

13. What constitutes populism is a contested issue, but it includes a claim to speak on behalf of the people, and a rejection of elites. Because populist leaders see themselves as embodying what the people truly want, they generally reject efforts to check or push back against their claims and actions. See, e.g., JAN-WERNER MÜLLER, WHAT IS POPULISM? (2016) (arguing that populism at its core is a rejection of 
literature on backlash, which focuses on the processes that engender politicization of IC rulings. What matters for our object of inquiry is that the issue is already socially divisive before an IC becomes involved or issues a ruling.

Whereas Hirschl created a single mega-political category that included domestic and international issues, this study focuses on the international adjudication and thus the internationalization of such disputes. The focus on the international level reflects our broader interest in the relative fragility of IC authority and the related IC strategies to increase their resilience. When considering why an internationally adjudicated dispute is mega-political, we theorize that the international adjudication of a domestic issue may in itself engender a reflexive reaction (referred to herein as sovereignty-driven megapolitics). That said, Hirschl would surely expect that a legal ruling could be just as polemic if it came from domestic judges. Indeed, domestic judges may intentionally pass the legal buck to the international level, preferring to let an outside body issue a ruling that is likely to be domestically contested. Meanwhile, because international adjudicators operate beyond the direct political reach of national governments, ICs may also be able to intervene in ways their domestic counterparts cannot. ${ }^{14}$ Part III develops further the particular mega-political issues that are likely to arise in an international adjudicatory venue.

Contrary to Hirschl, we posit that judicial involvement in mega-politics is not necessarily harmful for democracy. Hirschl associated mega-politics with hegemonic powers trying to lock in their agenda on fundamental questions involving a polity's identity. Against this backdrop, Hirschl made the case that majoritarian political solutions were preferable ways to address mega-political issues. Part III will address this concern. At this stage, what matters is that the involvement of courts, national or international, in mega-political disputes is generally an extension of rather than a counterpart to politics, which is to say that courts are involved because partisans seek to leverage favorable legal rulings.

While the litigants' motivation is surely political, Hirschl's concern was that adjudication would be used to either entrench a preferred outcome through constitutional lock-in, or that judicial resolution would substitute for an effort to resolve the issue politically or electorally. These are valid concerns. However, especially from the vantage point of contemporary politics and the resurgence of populism, it is far from evident that courts and constitutions necessarily entrench elite power, agendas, and prerogatives. To be sure, where courts wield power, one can expect politics to shape judicial appointment and judicial politics, and a form of political lock-in may then follow. But there is also a need to worry that executive branches may try to instill minority rule, weakening domestic political

pluralism); PIPPA NORRIS \& RONALD INGLEHART, CULTURAL BACKLASH: TRUMP, BREXIT, AND THE RISE OF AUTHORITARIAN-POPULISM 4-8 (2018) (distinguishing between nationalist populism, which mixes nationalism with populist rhetoric, and authoritarian populism, which mixes authoritarian values (e.g., the importance of security, value of conformity, and obedience towards strong leaders) with populist rhetoric). We focus on the nationalist side of populism because ICs are, by definition, outsiders associated with globalist agendas.

14. Alter, THE NEW TERRAIN OF INTERNATIONAL LAW, supra note 3, at 4-5. 
and legal institutions to the point that neither elections, nor parliamentary opposition, nor judges can check executive power. The intervention of ICs might further democracy by demanding checks that in themselves compel or nudge local partisans to find a legally defensible solution to issues that have riddled societies. ${ }^{15}$ And where democratic institutions are dysfunctional, judicial checks designed to uphold the constitution, individual rights, and a system of dispersed power may well be both politically popular and democracy-enhancing.

We also note that some international judicial intervention is countermajoritarian by design. International human rights obligations are intended to override majoritarian choice, precluding, for example, grants of amnesty for war crimes, the use of torture, or the criminalization of homosexual behavior, even if they run counter to dominant local sentiment. Sometimes international legal obligations clash with national constitutional obligations, setting domestic actors on a collision course with ICs, such as that seen in the interface of EU law and national constitutional law. ${ }^{16}$ And sometimes the costs associated with an international legal violation end up constraining democratic choice. For example, developing countries may fear the consequences of a decision to grant a compulsory license for a patented medicine or the consequences of creating temporary market barriers to protect national producers dealing with unforeseen market disruptions. For those who believe that human rights are worth protecting, that accountability for mass atrocities is important, or that international economic openness serves the long-term economic interests of countries, using international law to constrain government and majoritarian tendencies is precisely the point.

There are many reasons why ruling against the government is not a required part of this definition of mega-politics. In any system of judicial review, governments will occasionally find themselves on the losing side of litigation and the fact that a government loses will not in itself make an issue or a legal ruling controversial. This is especially so because sometimes politicians knowingly support unconstitutional or illegal acts to encourage their supporters, and sometimes these very same politicians want a court to stop the illegal acts from turning into precedent or binding law. Also, in inter-state disputes, the chances are certainly very high that one of the two litigant governments will be on the losing side. Especially if the issue is not mega-political, government lawyers may argue the position they believe to be the correct one or that has domestic backing, yet they may also not feel particularly strongly, or they may know their case is weak and unlikely to prevail. From an empirical perspective, it is important to note if government opposition increases the likelihood that adjudication of mega-

15. See generally SHAI DOTHAN, INTERNATIONAL JUDICIAL REVIEW: WHEN SHOULD INTERNATIONAL COURTS INTERVENE? (Cambridge, UK, Cambridge University Press, 2020) (noting that there can be democratic failures in domestic politics, where issues affecting minority or disenfranchised groups can be neglected in the absence of intervention by international bodies).

16. Karen J. Alter, National Perspectives on International Constitutional Review: Diverging Optics, in Comparative Judicial Review 244, 249 (Erin Delaney \& Rosalind Dixon eds., 2018). 
political issues leads to backlash proposals and efforts, meaning extraordinary claims and efforts to harm the authority of an IC or provoke dejudicialization. ${ }^{17}$ Since government opposition is neither necessary nor sufficient for an issue to be mega-political, it cannot be part of defining the phenomenon being studied here. That said, government opposition may be a necessary element for adjudication of mega-politics to engender dejudicialization, and it may be sufficient for, and thus part of what defines, the overlap between mega-politics and high politics litigation.

In sum, mega-political disputes involve substantive issues that deeply divide societies such that one can predict that at least one important social group will be upset by the outcome of international adjudication.

\section{III}

\section{StRuCtural CONTEXTS THAT GENERATE MEGA-POLITICS LiTIGATION}

Our definition of mega-politics involves investigating the international adjudication of issues that are already socially and politically divisive and contested. Whether and to what extent a society is divided about a topic are empirical questions that obviously can vary by social and political context and across time and space. For example, in Israel the question of religious exemption from military service is controversial because it touches on the fundamental questions of what it means for Israel to be a Jewish state. A religious exemption from military service is unlikely to be as polemical in a social context where few claim such exemptions, or where the exemption is not linked to the identity of a polity.

Given that the mega-political nature of an issue-area is context-specific and depends on the mobilization of a host of actors, it is impossible to precisely predefine a list of issues that are mega-political. Moreover, as politics is fluid and social preferences change and shift over time and in response to stakeholder politicization, we are also reluctant to impose a threshold definition of when an issue crosses into the zone of mega-politics. Each article included in this special issue will explain why the issue-area(s) the authors are investigating is megapolitical. Since we are operating in a target-rich environment, finding issues and cases that fit the category is not difficult. Rather than trying to define a threshold, this Part theorizes about the types of disputes that tend to engender the international adjudication of mega-politics.

We divide the types of IC cases that give rise to mega-political issues into three broad categories which might operate on their own or in combination: 1) inter-state disputes involving significant domestic social mobilization; 2) domestically divisive disputes where an $\mathrm{IC}$ is asked to resolve an issue that divides

17. Dejudicialization is "the complete removal from judicial cognizance of a policy issue that had previously been subject to judicialization." Daniel Abebe \& Tom Ginsburg, The Dejudicialization of International Politics? 63 INT'L STU. Q. 521, 521 (2019) [hereinafter Abebe \& Ginsburg, The Dejudicialization of International Politics?]. 
a single polity; and 3) sovereignty-based disputes where judicial intervention interferes with deeply held notions of state sovereignty. For now, we invoke these categories mainly to identify a broad set of issues that can be explored in empirical studies. However, some cases span the categories, and quite often partisans intentionally blur the categories to mobilize for or against IC intervention.

\section{A. Inter-State Driven Mega-Politics}

Inter-state driven mega-politics concerns disputes where important state interests diverge and where both the respective publics and governments of the disputing states perceive strong stakes in the outcome. Such a dispute by definition involves two or more countries, and thus the dispute spans borders. The dispute will be mega-political when something very significant is perceived to be at stake, when the state-parties are at loggerheads, and when at least one nation's society is mobilized for or against understandings of the law and issue.

Some territorial disputes, such as the on-going dispute between China and neighboring countries regarding the South China Seas, fall in this category of politically sensitive inter-state conflicts. What makes this high-stakes dispute mega-political is that the Chinese government and its neighbors have historic and longstanding commitments to their territorial claims, and the Chinese Communist Party has mobilized the Chinese public on the importance of the dispute to China's position as a world power. In addition, even if as a formal matter the actual arbitration only involved China and the Philippines, China's territorial claims adversely affect security, fishing, and free passage rights of a number of other countries in the region and beyond. The aggressiveness of China's position in this dispute, and the historical claims other states have to the same islands, also makes this case a litmus test for a broader set of issues and concerns. For this reason, one can well imagine this dispute regarding uninhabited rocks could provoke military hostilities. By contrast, other territorial disputes, such as the dispute between Canada and the United States over fishing rights and thereby implicitly territory in the Bay of Fundy, ${ }^{18}$ are not megapolitical because although fishing interests matter greatly, neither the governments nor larger segments of society see the issue as a fundamental threat to their legal rights or interests.

In Europe, the European Court of Human Rights (ECtHR) has experienced a surge of inter-state cases, some of which are about mega-political issues related to territory. Many of these cases stem from Russia's involvement in violent disputes over territory with neighboring countries. The Russo-Georgian War in 2008 , for example, prompted an interstate complaint (and thousands of individual applications). ${ }^{19}$ More recently, the Russo-Ukrainian warfare triggered an

18. Delimitation of the Maritime Boundary in the Gulf of Maine Area (Can./U.S.), Judgment, 1982 I.C.J. Rep. 560, II 22 (Nov. 5).

19. See, e.g., Georgia v. Russia (No. 1), Judgment, App. No. 13255/07, Eur. Ct. H.R. (2014); Georgia v. Russia (No. 2), Judgment, App. No. 38263/08, Eur. Ct. H.R. (2021); Georgia v. Russia (No. 3), App. 
interstate complaint ${ }^{20}$ Mega-political disputes concerning territory can also reach ICs more indirectly, as Salvatore Caserta and Pola Cebulak explain in their contribution. ${ }^{21}$ Caserta and Cebulak explore what they label international adjudication of territorial disputes by proxy. This occurs when "new-style" ICs, that is, regional economic and human rights ICs with compulsory jurisdiction and private access, adjudicate cases brought by individuals that are linked to an underlying territorial controversy between two or more states. ${ }^{22}$

The interstate category presumes that the two countries align differently on the international legal question. This category will often blur into the sovereignty-driven category insofar as governments insist that ICs should have no say on the issue. The more states and their populations are at odds with the substance of the law that ICs are called upon to adjudicate, and the more international law is not updated to reflect the changing circumstances of states, the more likely inter-state mega-political disputes will implicate ICs. In this respect, one wonders how climate change might present governments and judges with hard choices regarding whether to uphold existing international legal understandings and agreements. ${ }^{23}$ Governments might face the choice of respecting foreign property and contractual claims or providing locally produced food and energy to local populations. ICs might face the choice of defending contracts despite grave social costs for populations who were not part of the initial contractual bargain. Climate change inspired litigation may well become an issue that is sometimes litigated, and other times governments may simply refuse to export the promised goods. While out-of-court legal claims and counterclaims are not part of our inquiry, they are elements of judicialized international politics and judicialized mega-politics. For now, the point is that two countries may end up deeply divided on an issue and a specific case, on whether the international law in question is fair or legitimate, or on whether force majeure necessitates or should permit a derogation. These divisions may generate interstate mega-political legal disputes.

\section{B. Social-Cleavage Driven Mega-Politics}

This category of cases includes issues involving deep domestic social divisions and cleavages within a single polity that end up before ICs. There are various reasons why issues that may inflame strong cleavages in domestic societies end up in an international legal venue. In the European Union context, many issues that used to be domestically governed are now in whole or in part matters of European Union law. Notably, issues related to social-economic politics and

No. 61186/09, Eur. Ct. H.R. (2010).

20. Ukraine v. Russia (Re Crimea), Judgment, App. No. 20958/14, Eur. Ct. H.R. (2020).

21. Salvatore Caserta \& Pola Cebulak, Territorial Disputes by Proxy: The Indirect Involvement of International Courts in the Mega-Politics of Territory, 84 LAW \& CONTEMP. PROBS., no. 4, 2021, at 123.

22. Id. at 124 .

23. There are not many inter-state cases, pending or decided, concerning climate change, but Caserta and Cebulak discuss the recent dispute over the River San Juan in Central America brought before the ICJ. Id. at 132 . 
criminal law have caused controversies. Dorte Sindbjerg Martinsen and Michael Blauberger's contribution investigates how the European Union's Posted Worker Directive disrupted national practices ${ }^{24}$ putting pressure on an existing labor-capital social cleavage and engendering inter-state conflict between socialwelfare oriented member states and new members of the European Union.

James Thuo Gathii and Olabisi D. Akinkugbe's article focuses on a different type of cleavage-driven mega-politics, examining election disputes that end up in front of ICs. By definition, election cases represent situations where society is divided. Whether ICs have jurisdiction over domestic election disputes is sometimes part of the controversy. ${ }^{25}$ Yet if the government has used its incumbent powers to manipulate the election process, and should domestic courts be unwilling or unable to challenge the outcome, the likelihood of IC involvement increases. ${ }^{26}$ Election disputes often blur into the sovereignty driven mega-politics, discussed next, as the format of elections and their processes will typically be presented as constitutional and domestic political issues.

Human rights related cases often involve issues that implicate both constitutional and international individual rights. There are a number of human rights issues governed by international law that are hotly contested in different parts of the world. These issues include women's rights, the line separating state and religion, and the rights of minority groups or migrants. When international legal review generates substantially different legal interpretations than that of national law and national review, it may inflame a social cleavage that had been suppressed. Focusing on disputes involving lesbian, gay, bisexual, and transgender (LGBT) rights, Laurence Helfer and Clare Ryan investigate how international judicial intervention interacts with domestic social cleavages. ${ }^{27}$ Their analysis is particularly interesting because they find that adjudication of LGBT rights, which had been settled in many European countries, became increasingly mega-political over time. The increase arose as the ECtHR extended its case law to new and more controversial issues, and as some political leaders, especially in former-Soviet Bloc states, began to repress LGBT communities. Helfer and Ryan also explain how the ECtHR initially avoided mega-political controversies, and why avoiding such controversies has become more difficult over time.

24. Dorte Sindbjerg Martinsen \& Michael Blauberger, The Court of Justice of the European Union and the Mega-Politics of Posted Workers, 84 LAW \& CONTEMP. PROBS., no. 4, 2021, at 29.

25. James Thuo Gathii \& Olabisi D. Akinkugbe, Judicialization of Election Disputes in Africa's International Courts, 84 LAW \& CONTEMP. PROBS., no. 4, 2021, at 181.

26. Dmitry Kurnosov theorizes how the ECtHR should adopt a 'pragmatic' style in adjudicating election cases. See Dmitry Kurnosov, Pragmatic Adjudication of Election Cases in the European Court of Human Rights, 32 EUR. J. INT'L L. 255, 256 (2021).

27. Laurence R. Helfer \& Clare Ryan, LGBT Rights as Mega-Politics: Litigating before the ECtHR, 84 LAW \& CONTEMP. PROBS., no. 4, 2021, at 59. 


\section{Sovereignty Driven Mega-Politics}

Sovereignty driven mega-politics cases concern issues that involve one or more states where the issue is mega-political because an IC's involvement or a particular legal interpretation is seen by politicians as transgressing national sovereignty. For the mega-political definition to hold, the possibility of rallying significant public support behind the political position must also exist. Sovereignty is, however, a contested idea that can be hard to pin-down because political actors deploy the category vaguely and with plasticity. While not the only framework one might use, Stephen Krasner's categorization of the three forms of sovereignty is helpful because it highlights the different ways in which international law comes to be seen as intruding on sovereignty. ${ }^{28}$

Krasner separates three distinct forms of sovereignty. His key point is that these three forms of sovereignty are separable and not organically linked so that countries can have one form of sovereignty but be effectively missing another. ${ }^{29}$ International legal sovereignty is a form of externally conferred legal recognition that allows states to enter into contracts and treaties and become members of international organizations. The international community confers international legal sovereignty by recognizing a political entity as a "state," which in turn generates the state's legal right to enter into (and withdraw from) treaties and other international obligations. The second form, Westphalian-Vattelian sovereignty, conceives of sovereignty as an indigenous core right (in Krasner's words, it is "autochthonously generated") whereby "the state is not subject to any external authority, even authority structures that the state has itself voluntarily created through the exercise of international legal sovereignty." ${ }^{30}$ The third form, domestic sovereignty, is a contingent category that exists when states are "able to regulate and control activities within their territory." 31 The separability of these forms of sovereignty helps to explain why state consent to international adjudication may not matter to some political partisans who later take the position that IC review violates one or more of these forms of sovereignty.

International adjudication may run afoul of international legal sovereignty when an IC interprets a treaty obligation significantly differently from how governments understand the obligation. A legally technical but politically salient

28. Stephen D. Krasner, The Persistance of State Sovereignty, in INTERNATIONAL POLITICS AND InSTITUTIONS IN TIME 39 (Orfeo Fioretos ed., 2017) [hereinafter Krasner, The Persistence of State Sovereignty]. See also Neil Walker, The Sovereignty Surplus, 18 INT'L J. CONST. L. 370 (2020) for a fuller and more legally nuanced discussion of the many contours of sovereignty [hereinafter Walker, The Sovereignty Surplus].

29. Krasner provides examples to illustrate the three conceptions. Taiwan has Westphalian and domestic sovereignty, but not international legal sovereignty; Somalia has international legal and Westphalian sovereignty even though it lacks effective domestic sovereignty; and the Solomon Islands has international legal sovereignty despite lacking Westphalian and effective domestic sovereignty. See Krasner, The Persistence of State Sovereignty, supra note 28, at 41-42.

30. Id. at 3 .

31. Id. at 41 . 
example involves the longstanding disagreement between the World Trade Organization (WTO) Appellate Body and the US over the calculation of antidumping duties. American critics charge that the Appellate Body added legal restrictions that the US had not agreed to, thus violating its international legal sovereignty. ${ }^{32}$ WTO rulings on this issue have generated a strong governmental counter-response, ${ }^{33}$ yet the issue itself does not inflame social groups in the US or elsewhere. Instead of complaining about WTO rulings on this technical issue, critics lambast the WTO and its Appellate Body more generally, arguing that the WTO and its legal rulings compromise domestic sovereignty by applying rules that the US never consented to, undermining national regulatory choice. ${ }^{34}$ Lawyers might counter by arguing that the Appellate Body has not transgressed beyond the confines of WTO law, but this type of response speaks to international legal sovereignty while ignoring concerns about domestic sovereignty.

Actors who complain that international law cannot transgress national sovereignty are often implicitly invoking Krasner's category of Westphalian/Vattelian sovereignty. Often a rather vague notion, the claim is that IC review is trampling a core element of what it means to be sovereign. ${ }^{35}$ Those who make a Westphalian sovereignty argument typically claim that national legislation and executive decisions that are validly adopted under domestic procedures should ipso facto be beyond international legal scrutiny. Authoritarian leaders, democracies predicated upon the idea of parliamentary supremacy, and national legal systems that reject judicial review may be especially likely to invoke Westphalian sovereignty in response to disfavored international rulings. This is so even if the state has joined international treaties and implemented consequential legislation. For example, international rules concerning the treatment of migrants, asylum seekers or foreign workers may be seen as core sovereignty intrusions notwithstanding that states have bound

32. In the United States' view, WTO law was crafted to allow for the US practice of 'zeroing.' See generally William W. Nye, The Implications of "zeroing” for Enforcement of US Antidumping Laws, 12 J. ECON. POL'Y REFORM. 263 (2009) (explaining the conflict between the US and the WTO on the issue of zeroing).

33. US executive branch's anger on this issue has led it to block appointments to the WTO Appellate Body, ultimately resulting in the de facto suspension of that IC. See Greg Shaffer, Manfred Elsig \& Mark A. Pollack, US Threats to the WTO Appellate Body (Univ. of Cal. Sch. of Law Research Paper No. 201763, 2017), https://papers.ssrn.com/sol3/papers.cfm?abstract_id=3087524 [https://perma.cc/WPF9-SF6G].

34. Claude Barfield sees the "judicialized" WTO as politically unsustainable because member states disagree about complex regulatory issues, and the WTO's adjudicatory mechanism will be called upon to disputes where the legal texts "contain gaps, ambiguities and contradictory language." Creating law will, in his view, raise "intractable questions of democratic legitimacy." Claude E. Barfield, Free Trade, Sovereignty, Democracy: The Future of the World Trade Organization, 2 CHI. J. INT'L L. 403, 408 (2001) [hereinafter Barfield, Free Trade, Sovereignty, Democracy: The Future of the World Trade Organization].

35. As Neil Walker explains, the sovereignty claims have proliferated over time. Walker is mainly examining scholarly discussions of sovereignty, yet he notes that "sketchiness and contentiousness colors the academic treatment of sovereignty", and he argues that the ways the concept is invoked generate unanswerable questions. See Walker, The Sovereignty Surplus, supra note 28, at 371-72. 
themselves to international rules regarding these policies. ${ }^{36}$ This claim is often made in conjunction with an international legal sovereignty claim that the IC in question has illegitimately expanded the agreed treaty while potentially also acting ultra vires.

In this special issue, Silvia Steininger \& Nicole Deitelhoff explore the question of the international adjudication of peace and security conflicts. ${ }^{37}$ At the heart of these conflicts are core principles of international law concerning nonintervention and territorial sovereignty, and the prohibition of aggression. Yet, developments in international criminal law have intruded on some of these principles, notably by the attribution of criminal responsibility for certain very serious international crimes. Steininger and Deitelhoff show how this development collides with basic ideas of sovereignty and creates mega-politics. Yet, they also demonstrate that notwithstanding the sovereignty concerns, the turn to ICs can mitigate conflicts, for instance by slowing them down and creating new and common spaces for solving conflicts.

A final sovereignty-related category involves jus cogens and international criminal law. For example, peremptory norms, which are not constrained by formal notions of consent, may prevent states from providing amnesties for certain crimes. Absent jus cogens norms (or specific international human rights agreements), the decision to grant amnesty would be a sovereign prerogative determined by domestic legal bodies and not subject to international review. And, absent international adjudication, government violations of their national jus cogens rights may remain unnamed and unchecked. In this special issue, Hélène Ruiz Fabri and Edoardo Stoppioni consider how the category of jus cogens generates inter-state clashes, identifying how complaints are about both international legal sovereignty and Westphalian sovereignty. ${ }^{38}$

Examples reveal that the sovereignty category may or may not engender mega-politics. In the WTO example, the US government was upset that the WTO dispute settlement kept condemning its zeroing practice, but this concern did not inflame public passions. The specific concerns have been redirected at targets that are more likely to inflame the public. For example, President Trump politicized trade imbalances with China, blaming the WTO for failing to stop China's "illegal" practices. It is not clear which Chinese practices the U.S. considers illegal, but the larger issue is that WTO membership has constrained US policy and the WTO's legal system did not vindicate the Trump administration's sense that China had violated WTO law. These WTO examples highlight the malleability of invoking the sovereignty category to transform a

36. See generally Mikael Rask Madsen, Two-Level Politics and the Backlash against International Courts: Evidence from the Politicisation of the European Court of Human Rights, 22 BRIT. J. OF POL. \& INT'L REL. 728 (2020) (exploring whether international institutions are more susceptible to political backlash than domestic ones due to the dual nature of international politics).

37. Silvia Steininger \& Nicole Deitelhoff, Against the Masters of War: The Overlooked Functions of Conflict Litigation by International Courts, 84 LAW \& CONTEMP. PROBS., no. 4, 2021, at 95.

38. Hélène Ruiz Fabri \& Edoardo Stoppioni, Jus Cogens before International Courts: the MegaPolitical Side of the Story, 84 LAW \& CONTEMP. PROBS., no. 4, 2021, at 153. 
fairly ordinary legal suit into a mega-political dispute, in this case by channeling deep disagreements over global trade fairness and geopolitics towards the WTO and its legal system.

D. The Three Categories of Mega-Politics

These three categories of mega-political issues that may be brought before ICs are expanded upon in Table 1 below. The first category, interstate driven mega-politics, implicates more than one state by definition. The second and third categories, social cleavage and sovereignty-driven mega-politics, may involve only one state, but the generalizability of the issue to other states can raise concerns and trigger reactions in countries that are not themselves parties to the dispute. Because adjudicating mega-politics is politically sensitive, for all three categories, countries that are not part of the dispute may be concerned enough to lend support to backlash efforts of the more directly impacted countries. As is apparent from the discussion, some issues may fit into more than one category, for example, election disputes. 
Table 1: Three categories of mega-political issues

\begin{tabular}{|c|c|c|c|}
\hline & $\begin{array}{l}\text { Inter-state driven } \\
\text { mega-politics }\end{array}$ & $\begin{array}{l}\text { Social cleavage driven } \\
\text { mega-politics }\end{array}$ & $\begin{array}{l}\text { Sovereignty driven } \\
\text { mega-politics }\end{array}$ \\
\hline $\begin{array}{l}\text { Nature of } \\
\text { the issue }\end{array}$ & $\begin{array}{l}\text { Disputes where } \\
\text { important state } \\
\text { interests diverge, and } \\
\text { where not only } \\
\text { governments but also } \\
\text { peoples within the } \\
\text { disputing states } \\
\text { perceive a strong } \\
\text { stake in the outcome. }\end{array}$ & $\begin{array}{l}\text { Disputes involving } \\
\text { domestic issues that } \\
\text { end up in an } \\
\text { international } \\
\text { adjudicatory venue. } \\
\text { Strong cleavages in } \\
\text { domestic societies } \\
\text { undergird the dispute, } \\
\text { and there may well be } \\
\text { transnational } \\
\text { divergence in social } \\
\text { support for and against } \\
\text { the issue. }\end{array}$ & $\begin{array}{l}\text { Disputes mostly } \\
\text { involve one country. } \\
\text { They are mega- } \\
\text { political because } \\
\text { international } \\
\text { adjudicators are } \\
\text { intervening in issues } \\
\text { many regard as } \\
\text { national or sovereign. }\end{array}$ \\
\hline Examples: & $\begin{array}{l}\text {-Territorial disputes } \\
\text { (ex. Cyprus, Crimea, } \\
\text { South China Seas, } \\
\text { etc.) } \\
\text {-Currency } \\
\text { manipulation, with a } \\
\text { market economy } \\
\text { versus state owned } \\
\text { enterprises/subsidies } \\
\text {-Torture as it } \\
\text { intersects with } \\
\text { terrorism } \\
\text {-Economic shocks } \\
\text { triggering a need for } \\
\text { exceptions regarding } \\
\text { int'l contracts \& } \\
\text { trade (e.g., sov debt + } \\
\text { bailouts) } \\
\text {-Peace settlements } \\
\text { after mass atrocities }\end{array}$ & $\begin{array}{l}\text { - LGBTQ+ rights } \\
\text { versus 'traditional' } \\
\text { values } \\
\text {-Secular versus } \\
\text { religious divisions } \\
\text {-Migration versus } \\
\text { citizenship rights } \\
\text { - Free mobility versus } \\
\text { welfare rights } \\
\text {-Women's rights versus } \\
\text { patriarchal values } \\
\text {-Election disputes } \\
\text { (national elections that } \\
\text { end up disputed in int'l } \\
\text { venues) }\end{array}$ & $\begin{array}{l}\text {-Prosecuting heads of } \\
\text { state } \\
\text {-Amnesty laws \& } \\
\text { right to exile } \\
\text {-Intellectual property } \\
\text { as it implicates access } \\
\text { to medicine } \\
\text {-Election disputes } \\
\text { (national elections } \\
\text { that end up disputed } \\
\text { in int'l venues) } \\
\text {-Some disputes with } \\
\text { foreign investors. }\end{array}$ \\
\hline
\end{tabular}

E. Do These Categories Predict IC Involvement in Mega-Politics or Backlash Against ICs?

Table 1 categorization considers whether the structure of the dispute, as primarily inter-state or domestic in nature, shaped whether international adjudication became more or less contested. One might imagine, for example, that an IC's jurisdiction over an inter-state dispute might be less contested either because the two parties consented to international adjudication or because 
domestic courts would not be able to rule on the case themselves. A similar logic would lead us to expect that sovereignty-driven disputes might be especially polemical precisely because, absent international law, the contested action might be fully legal or national courts would be left alone to resolve the dispute. Indeed national-populist backlash against ICs seems to be largely inspired by the sovereignty category. ${ }^{39}$ And the "nationalist" part of national-populism could generate controversy around inter-state disputes. This Article's suppositions that the source of the conflict might generate insight about the likelihood of megapolitics or backlash, however, quickly broke down once applied to concrete cases. In particular, contributors to this special issue found that disputes often involve more than one of these categories.

The blurring of categories may be intentional and part of political strategies. Even if an analyst can firmly locate a dispute in one specific category (for example, the WTO example of a zeroing dispute is an inter-state dispute), partisans may frame a dispute as falling within various categories in an effort to mobilize political support. For example, Zimbabwe's attack on the Southern African Development Community Tribunal (SADCT) seemingly derived from sovereignty-driven mega-politics. Indeed, Zimbabwe's President's immediate reaction was to dismiss the ruling by arguing that "Some farmers went to the SADC [T]ribunal in Namibia, but that's nonsense, absolute nonsense, no one will follow that ... We have courts here in this country, that can determine the rights of people. Our land issues are not subject to the SADC [T]ribunal." ${ }^{40}$ Tendayi Achiume would challenge the definition of this dispute as sovereignty-driven. Achiume argues that the farmer's case was also a social cleavage driven case that pitted landless Zimbabweans against white landowners, and that reanimated nationalist freedom fighters in their desire to challenge the post-colonial settlement. ${ }^{41}$ Recognizing that other Southern African governments could have their own concerns, as the mega-politics unfolded, Zimbabwe's President Mugabe's attacks on the Tribunal were wide ranging. His government's claims involved international legal sovereignty complaints contesting the validity of the SADCT, inter-state complaints about a European-funded SADCT imposing colonial legacies, and diplomatic appeals where Zimbabwe's Minister of Justice warned other SADC countries that the Tribunal might also intervene in their domestic land dispute cases. ${ }^{42}$

39. See Voeten, supra note 6. It is also true, however, that right-leaning populist leaders tend to target minorities, migrants, and issues that they can negatively associate with political opponents. Populist leaders may even welcome international adjudication because it provides an opportunity for them to mobilize their members in opposition to external interference.

40. Alter et al, Backlash against International Courts in West, East and Southern Africa, supra note 6 , at 309 .

41. She further notes how the Zimbabwean social cleavage also resonated in South Africa, where the issue of post-colonial land redistribution remained politically sensitive. E. Tendayi Achiume, The SADC Tribunal: Sociopolitical Dissonance and the Authority of International Courts, in INTERNATIONAL COURT AUTHORITY 124 (Karen J. Alter, et al. eds., 2018).

42. Alter et al, Backlash against International Courts in West, East and Southern Africa, supra note 6 , at 310-14. 
The point is that politicization may make the root classification analytically irrelevant as the dispute evolves. Or it may well be that issues become more politically divisive when an issue can be framed as involving more than one of the categories identified. This uniting of the three frames can help to build a coalition of opposition to IC involvement, and IC involvement may in turn be used to mobilize support against a larger set of institutions and actors. In other words, the backlash politics may well be larger than the dispute or the legal issue in question, in which case international judges may find that no matter what they do, the ruling will become a lightning rod of political contestation. ${ }^{43}$

These three categories nevertheless help us understand why compared to the past, ICs today are increasingly involved in adjudicating mega-politics. The categories also help to define a set of issues that scholars might investigate. The categories could even have predictive value. If one, for example, studied the range of issues that ICs adjudicate, one could well find that state parties are more likely to seek a political settlement for cases that fall into these three categories, regardless of the clarity of an international law violation, because all involved want to avoid a potentially explosive or precedential ruling on the merits of the case. For the purpose of this study, what matters is that the categories help identify the basic contours of the disputes we are studying. The categories moreover help to explain why it is difficult for ICs to avoid entering into megapolitical cases. The framing plasticity of the sovereignty category, in particular, further helps us understand why IC authority may be affected and backlash sentiments provoked even if the IC never ends up ruling on the merits of a megapolitics dispute.

\section{IV}

\section{INTERNATIONAL COURTS AND MEGA-POLITICS: CHALLENGES AND STRATEGIES}

This Part identifies the challenges and risks that international judges face in dealing with mega-political cases, identifies some strategies that judges draw on to navigate this fraught terrain, and discusses how entering into mega-political disputes may affect IC authority.

\section{A. The Distinctive Challenges of International Adjudication of Mega-Politics}

There are two general concerns about the adjudication of mega-politics, especially in the context of functioning democracies: 1) that political means would be better at resolving the dispute, and 2) that courts will be unable to helpfully contribute to the resolution of a conflict. Politically brokered solutions may be preferable, especially if inducements can be added to the bargain, if political negotiators have greater political legitimacy, and if consent makes

43. See generally Karen J. Alter \& Michael Zürn, Conceptualizing Backlash Politics: Introduction to a Special Issue on Backlash Politics in Comparison, 22 BRIT. J. POL. AND INT'L REL. 563 (2020) (explaining the factors that animate backlash politics). 
compliance more likely. But a preference for a political solution is often beside the point. Frequently mega-political disputes end up in court because politics has not resolved the issue, or because policymakers side-stepped opponents, in some cases violating procedural or substantive law requirements. That said, critics of the judicialization of international relations lament using ICs as appeals chambers for political choices that from a domestic perspective are substantively and legally defensible. This sentiment, understandable as it is, offers scant guidance for judges who are presented with a well-founded legal suit that falls squarely within their jurisdiction.

The second claim, that judicial intervention will not help, is something that lawyers and social scientists have debated in-depth. Scholars have long observed that adjudication is least effective in certain contexts. For example, Lon Fuller expected adjudication to be ineffective or a failure vis-a-vis polycentric problems, meaning where there are multiple centers and thus "many affected parties and a somewhat fluid state of affairs." 44 Mega-political cases present additional concerns. The political salience of the issue is likely to infect the adjudicatory process, increasing the scrutiny and pressure on judges and perhaps even mobilizing antagonists to obfuscate or stymie the legal process by withholding, contradicting, or despoiling evidence as a strategy for criticizing an anticipated judicial outcome.

That mega-political cases are both polycentric and highly politicized puts international judges in a complex position. Judges could find a way to avoid ruling, using some of the techniques this Part will soon discuss. Yet especially if a legal case is carefully selected and constructed to fit squarely within an IC's jurisdiction, international judges might face a binary choice: they can either rule on the merits as best they can, create a de facto reality that can leave a government's questionable international legal interpretations unaddressed, or render courts or legal justice inconsequential or even unavailable.

A less voiced concern is that the international adjudication of mega-politics might provoke a political reaction that leads to the dejudicialization of an IC or the elimination of legal access so that clear legal violations can no longer be adjudicated. This radical solution is rare but not unheard of.$^{45}$ The conclusion to this special issue will return to this topic. A salient point for now is that

44. Lon L. Fuller \& Kenneth I. Winston, The Forms and Limits of Adjudication, 92 HARV. L. REV. 353, 397 (1978). Fuller worried that polycentric contexts would generate inadequate participation by stakeholders, rendering judges insufficiently informed and "ill-equipped to determine the complex repercussions of a proposed decision." J. W. F. Allison, Fuller's Analysis of Polycentric Disputes and the Limits of Adjudication, 53 THE CAMBRIDGE L. J. 367, 370 (1994).

45. Unhappy governments blocked appointments to the SADC Tribunal and the WTO appellate body, forcing the IC's shut down. The WTO system is not entirely shut down, since panels can still adjudicate cases. The SADC Tribunal is, at this point, non-existent because the new Protocol on the Tribunal on The Southern African Development Community has yet to be ratified by SADC members. See Barfield, Free Trade, Sovereignty, Democracy: The Future of the World Trade Organization, supra note 34 (regarding the WTO). See also Alter et al, Backlash Against International Courts in West, East and Southern Africa, supra note 6 (on the SADC Tribunal). 
dejudicialization can only be enacted by states, and it is very rare. ${ }^{46}$

So long as ICs still exist and exercise jurisdiction over inter-state controversies, issues where there are deep domestic divisions, and issues that touch on the sovereignty of states, we can expect ICs to adjudicate mega-political disputes. The question then becomes: how should or do ICs proceed, and how does adjudication of mega-politics affect IC authority?

\section{B. International Judicial Strategies for Politically Sensitive Cases}

ICs are used to navigating around politically charged legal suits. Focusing on what he calls avoidance strategies, Jed Odermatt identifies a range of interpretive techniques that ICs have used to sidestep ruling on highly political cases, including deciding that a case is 'non-legal' in nature, finding that a 'dispute' does not actually exist, rejecting the standing of the complainant or finding that the case is not admissible, deferring to political bodies or national decision-makers, and minimizing the dispute to avoid or limit political controversy. ${ }^{47}$ Another strategy involves stalling the case in the hopes that the case will settle or that a key player may leave the political stage. ${ }^{48}$ If these strategies fail because, for example, the case falls squarely within an IC's remit and both the law and the violation are clear and obvious, judges can turn to strict legal formalism. They can set a high threshold of proof to assess the evidence presented by the parties, shrink the precedential value of a ruling, reframe the legal question to render it smaller and more technocratic, or hew closely to the wording of relevant legal texts. ${ }^{49}$ Skillful legal formalism shifts the blame to the law's drafters, signaling to litigants that they should focus on changing the law rather than shooting the messenger. Moreover, in some instances, ICs can defer the cases back to national authorities, for example via the principle of complementarity in international criminal law as shown by Steininger and Deitelhoff, or through strict

46. IC dejudicialization is enacted in three ways: 1) by states exiting an international agreement; 2) by states exiting the jurisdiction of an IC; 3 ) by a collective action of governments to change controversial legislation or the IC's mandate. If states do not want to exit an agreement (option 1), are unable to leave an IC's jurisdiction (option 2), and lack support to change the IC's mandate (option 3), the only strategy left is to ignore the court or to try to sabotage the legal process. See Abebe and Ginsburg, The Dejudicialization of International Politics?, supra note 17, at 525-26, for an explanation of why dejudicialization is so rare.

47. Jed Odermatt, Patterns of Avoidance: Political Questions before International Courts, 14 INT'L J. L. CONTEXT 221, 227-3 (2018).

48. An example of drawn out proceedings are the disputes over land rights after the de facto division of Cyprus in 1974 described by Salvatore Caserta and Pola Cebulak in this issue, supra note 21. These highly divisive cases were only starting to be resolved by the European Court of Human Rights (ECtHR) more than two decades after the division of Cyprus. See, e.g., Lozidou v. Turkey, Case No. 40/1993/435/514, (Eur. Ct. H.R. 1996).

49. Alter and Helfer discuss how the Andean Tribunal uses legal formalism to avoid political pushback, stating that "formalist reasoning may be a prudent strategy for tribunals that face legally and politically inhospitable environments."). See KAREN J. AlteR \& LAURENCE R. HELFER, TRANSPLANTING INTERNATIONAL COURTS: THE LAW AND POLITICS OF THE ANDEAN TRIBUNAL OF JUSTICE 17 (2017). See also Mikael Rask Madsen, The Narrowing of the European Court of Human Rights? Legal Diplomacy, Situational Self-Restraint and the New Vision of the Court, 2 EuR. CONVENTION ON HUM. RTS. L. REV. (2021). 
interpretation of provisions related to the exhaustion of domestic remedies. ${ }^{50}$

Not only will a formalist blame avoidance strategy not always work, but judges may also not want to prioritize avoiding blame over other goals such as developing or defending the law. The larger spirit of the law, the goals of the relevant legal system, or the needs of justice might also be such that judges cannot or do not want to avoid issuing a substantive legal ruling. The contributions to this special issue consider how ICs navigate the fraught cases that are presented to them. Martinsen and Blauberger see the CJEU as having engaged the legal issue head on, and they suggest that the CJEU's intervention helped diffuse some of the contestation surrounding the Posted Workers Directive by balancing the interests of affected actors. ${ }^{51}$ Helfer and Ryan see the ECtHR as having applied an equality and non-discrimination perspective that for decades facilitated the expansion of LGBT legal protections without triggering significant pushback or backlash. Yet the authors also worry about whether this balancing act can be maintained in the face of a new set of LGBT rights disputes and the emergence of social cleavages over LGBT rights in several Council of Europe member states. ${ }^{52}$ Gathii and Akinkugbe explain why African nationals continue to bring electoral disputes to African ICs, even if their legal concerns about the contested election are seldom, if ever, vindicated. Their analysis suggests that African ICs sidestep issuing controversial rulings on the merits, yet African IC involvement is nonetheless seen as valuable by the litigants and by Gathii and Akinkugbe..$^{53}$ Steininger and Deitelhoff show how ICs' involvement in peace and security disputes serve a number of functions, ranging from slowing down conflicts and creating good offices to clarifying legal norms. ${ }^{54}$ These are four examples of ICs entering contested territories and providing something that stakeholders value without inciting dejudicialization. The conclusion to the special issue returns to this topic, drawing from the special issue contributions to identify ways that ICs enter the political fray while avoiding inciting backlash and dejudicialization.

\section{Impact of Adjudicating Mega-Politics on IC Authority}

While not all resistance to ICs challenges IC authority or seeks dejudicialization, the focus on mega-politics is intended to help us think about the more severe category of backlash against ICs. ${ }^{55}$ Backlash is typically defined

50. Steininger \& Deitelhoff, supra note 37; see generally Madsen, supra note 49 (discussing formalism and the interpretation of procedural requirements).

51. Martinsen and Blauberger, supra note 24.

52. Helfer \& Ryan, supra note 27.

53. Gathii \& Akinkugbe, supra note 25.

54. Steininger \& Deitelhoff, supra note 37.

55. Some scholars introduce a distinction between pushback and backlash where pushback, the most common response, is seen as an ordinary form of resistance concerning the direction of the law, whereas backlash is seen as involving extraordinary attacks on the judicial institution and its authority. See, e.g., Madsen et al., Backlash Against International Courts, supra note 6, at 198 (stating that pushback occurs when individual Member States seek to influence the future of case law but backlash occurs in critique to a significant institutional reform). 
as extraordinary efforts by governments to reverse a contested ruling, usually through dejudicialization. ${ }^{56}$ The previous Part noted that complete dejudicialization, or the stripping of IC authority to adjudicate a range of cases, is rare. One reason for its rarity is that it is so much easier to work out a political compromise or to simply ignore an adverse IC legal ruling. The special issue contributors focused on litigation of politically charged mega-politics issues, yet in no case was the result of the litigation a dejudicialization of ICs' ability to intervene in the future. However, even if dejudicialization efforts are never articulated or fail to achieve their stated goals, deeply felt animosity and resistance may adversely affect an IC's authority and influence. ${ }^{57}$ To explain this point, this Part draws on the authority framework developed by Karen J. Alter, Laurence R. Helfer and Mikael Rask Madsen. ${ }^{58}$

Alter et al. define IC authority as an IC's "ability to influence practices in law, politics and society. ${ }^{" 59}$ More specifically, IC authority is a court's ability to project its ideas and values about the law and to have these projections reflected by, or even internalized in, the actions of individuals, groups, and organizations in society." ${ }^{60}$ Their framework sees IC authority in relational terms and as existing across a continuum that includes "no authority in fact," narrow authority (an ability to influence the litigants), intermediate authority (the ability to influence similarly situated litigants), extensive authority (the ability to influence the practices of the broader legal field of actors, like lawyers and in-house counsels, legal scholars, civil society groups, and bar associations), and popular authority (the ability to induce respect in the general public). ${ }^{61}$ Government resistance can directly shape an IC's narrow authority, and vociferous resistance may also influence intermediate, extensive and popular authority ${ }^{62}$ The point is that, should the various audiences that pressure others to comply with international law begin to ignore IC rulings, to stop seeing IC rulings as binding, or to stop agitating for respect for international law, the adjudication of mega-political disputes may contribute to a de facto dejudicialization where the IC's formal authority remains intact, but "despite identified violations, litigants do not file complaints with the IC, and cases that the court does decide are generally ignored." 63

56. See Caserta \& Cebulak, supra note 21.

57. See Alter, The High Water Mark of International Judicialization?, supra note 10, at 14-17 (stating dejudicialization can shrink IC's authority, but IC authority will also be undermined if fewer audiences accept the binding nature of the rulings).

58. Alter et al., International Court Authority, supra note 5, at 24.

59. Id. at 13 .

60. $I d$.

61. Id. at 31-33.

62. The focus on this broader range of actors builds on Alter's argument that ICs influence states and politics by connecting with compliance partners and compliance supporters within states. See Alter, The New Terrain of International Law, supra note 3, at 61 (citing concerns about compliance partners harming rather than helping compliance supporters).

63. Alter et al. call this a situation where ICs have "no authority in fact." International Court Authority, supra note 5, at 31 . 
The concern about undermining IC authority is where the question of the international adjudication of mega-politics intersects with debates about backlash and populism. Focusing specifically on national populism and ICs, Erik Voeten elaborates the many reasons for populist leaders' backlash against ICs, highlighting the clash between illiberal populist values and liberal international law. ${ }^{64}$ Voeten notes that populists do not oppose all institutions, only institutions that do not, in their view, produce morally correct outcomes, and he finds that not all populist leaders oppose ICs or their rulings. ${ }^{65} \mathrm{But}$ eighteen of the twentyeight instances that meet Voeten's definition of backlash were instigated by populist leaders, ${ }^{66}$ and contestation involved liberal issues that populists typically deride (private property rights, minority rights, and identity-related issues) ${ }^{67}$ Voeten adds important nuances, which help us to understand why not every populist leader exercises their right to withdraw from an IC's jurisdiction, and why populist revolts do not necessarily translate into a shrinking of IC authority. Insofar as Voeten sees populism as creating social divisions around certain issues, his analysis overlaps with this article's category of social cleavage driven megapolitics.

But our point is different. We see populism as creating an inherent and unavoidable risk for IC authority insofar as ICs are tasked with applying rules that populist leaders have already mobilized against. On the one hand, we do not presume that a populist backlash harms an IC's authority (indeed Voeten notes that many of the instances of backlash he identifies do not succeed in their substantive goal). If the only outcome is that populist leaders do not participate in international litigation or comply with specific IC rulings, an IC's narrow authority (its ability to influence the parties to the dispute) may be undermined at the same time that its intermediate authority (its ability to influence similarly situated litigants) and its extensive authority (support within the national legal field) may be bolstered.

On the other hand, if populist leaders voice arguments that have a broader popular resonance, even if these arguments have little to no bearing on the legal case at hand, populism might undermine popular authority. Also, populist leaders might attack or remove the key domestic officials that are involved in generating an IC's intermediate authority. By associating international law with elite and Western values, by reminding citizens that ICs compromise national sovereignty, and by framing even reasonable IC rulings as a fundamental threat

64. Voeten, Populism and Backlashes Against International Courts, supra note 6, at 408-12. Voeten argues that many backlashes against ICs occur because ICs are seen as elite institutions that promote liberal principles such as property rights and human rights.

65. Id. at 412.

66. Id. at 410. For Voeten, backlash includes a state's concrete proposals to curb an IC's authority and a state-level decision to exit from an IC's authority, regardless of whether the efforts succeed. Id at 408-10. This is the same definition used by Alter, Gathii and Helfer. Alter et al., Backlash Against International Courts in West, East and Southern Africa, supra note 6.

67. Id. at 414-17; see generally Eric A. Posner, Liberal Internationalism and the Populist Backlash, 49 ARIZ. STATE L.J. 795 (2017) (describing a different and broader set of issues identified by populists). 
to the national constitution or national identity, populist resistance can build into a larger backlash politics aimed at questioning the political value of specific international institutions (e.g. the European Union, human rights treaties), of a more internationally open national orientation, of multilateralism, and of the rule of law more generally. ${ }^{68}$

Our larger point is that whether resistance, populist or other forms, actually undermines an IC's authority, contributes to social peace, or resolves the dispute depends on how other actors or audiences respond to such resistance. ${ }^{69}$ More extreme efforts to dejudicialize or sanction an IC often fail because constellations of other actors come to the rescue of the court and help it survive moments of crisis. ${ }^{70}$ Yet even if an IC's formal legal (e.g. its de jure) authority remains intact, its de facto authority may be diminished. We will return to this issue in the conclusion to this special issue.

This Part has identified strategies that ICs can use to avoid issuing contentious rulings. While avoidance strategies exist, and they have sometimes been applied to rulings as discussed by our contributors, ICs have also issued rulings on the merits in all of the issue areas studied in this special issue. The questions this Article raises, but is unable to definitively answer, are when and how the IC's overall authority is undermined by adjudicating mega-political disputes. These are tricky questions, as in order to understand if IC authority is increased or decreased by the adjudication of mega-political disputes, we would need to know the pre-dispute baseline of IC authority. This special issue's conclusion returns to this topic, drawing on the articles in this special issue to explain how ICs engage and seek to minimize an adverse political response to their engagement.

68. Here we are drawing on the definition of backlash politics articulated by Alter and Zürn, where backlash politics involves extraordinary tactics that challenge dominant scripts, has an overall retrograde objective of returning to a real or imagined prior condition (in this case, the condition of absolute sovereignty), and backlash complaints enter political discourse. See Alter \& Zürn, Conceptualizing Backlash Politics: Introduction to a Special Issue on Backlash Politics in Comparison, 22 BRIT. J. OF POL. AND INT'L REL., 563, 566-68 (2020).

69. See id; Madsen et al., Backlash Against International Courts, supra note 6, at 201 (stating IC's can adopt particular strategies to respond to backlash and this is influenced by different constellations of actors).

70. See Karen J. Alter, Who are the "Masters of the Treaty?": European Governments and the European Court of Justice, 52 INT'L ORG. 121, 135-42 (1998) (discussing numerous failed attempts against the Court of Justice of the European Union). See generally, Karen J. Alter, Establishing the Supremacy of European Law: The Making of an International Rule of Law in Europe (2003) (expanding on examples discussed in her earlier article). A more recent example is the attempt by the Danish government to push back against the ECtHR in 2017 and 2018 with the goal of regaining political and sovereign control over policy-areas they argued were of critical political importance with regard to migration. This push was met with a counter-mobilization involving both other member states and civil society, resulting in a much revised and subdued reform proposal, the Copenhagen Declaration. See Madsen, supra note 36 (analyzing the Danish example at length throughout); Alter et al., Backlash Against International Courts in West, East and Southern Africa, supra note 6, at 216 (discussing the same issue of countermobilization against challenges to ICs in African sub-regional courts). 


\section{V \\ OUTLINE OF THE SPECIAL ISSUE}

This Part previews the studies included in this special issue, focusing on how they engage the concept of mega-politics as reframed in this introduction. Each set of contributors to this special issue was asked to select a mega-political topic to consider, to explain why the issue was mega-political, and to choose a specific focus. The scope of the inquiry is national, transnational, and international. The case-studies are written by an interdisciplinary group of experts of international courts and generally involve both junior and senior scholars.

Dorte Sindbjerg Martinsen and Michael Blauberger's article "The Court of Justice of the European Union and the Mega-Politics of Posted Workers" examines the hotly contested issue of the labor rights of workers from one European country who are temporarily employed in another European country. ${ }^{71}$ The authors explain that this issue generated problems based on the differential labor and social regulations of member states, putting rules on the freedom of services in a collision course with labor regulations, which many member states see as falling within their sovereign prerogative. Through a provocative analysis of newspaper coverage of the political debates and Court of Justice of the European Union (CJEU) legal rulings in five countries from 2000-2020, the authors find that the issue was already politicized before the CJEU ruled, in large part because European enlargement disrupted a careful political balance achieved among pre-enlargement member states. They argue that the CJEU first tried to rebalance the diverse interests, issuing rulings that proved highly controversial. It then stepped back, parsing the responsibility for determining the relevant rights to implicated states. The authors process-trace the interaction of CJEU rulings with different political attempts to resolve the conflict legislatively. The judicial-legislative interaction, although controversial, ultimately helped to quiet tempers, and the authors see the CJEU as crucial in helping to craft a workable solution. The overall finding is that while the CJEU's "Laval quartet" rulings became a lightning rod of contestation, the heart of the problem came from conflicts of law, not the CJEU per se. By trying to help craft solutions, and later deferring to member state solutions, the CJEU both weathered the storm and helped to right the ship.

Silvia Steininger and Nicole Deitelhoff's article "Against the Masters of War: The Overlooked Functions of Conflict Litigation by International Courts" examines adjudication of violent conflict in various guises and legal venues. ${ }^{72}$ Focused on the mega-politics involved in adjudicating these cases, the authors argue that one cannot say that international judicial intervention is harmful to the goals of democracy, the peaceful resolution of disputes, or the legal norms in question. Even if the parties ignore the ruling or use it to rally their forces, the authors argue that judicial involvement has clearly been helpful for instantiating

71. Martinsen \& Blauberger, supra note 24.

72. Steininger \& Deitelhoff, supra note 37. 
what this introduction has called the intermediate and extensive authority of ICs and of the law in question. Moreover, when litigation is embraced by both sides, judicialization buys time, interjects legal concerns, and creates a space and process for partisans to work out their differences. Even in cases where the various sides reject and capitalize on litigation for their own purposes, the authors reject the validity of a counterfactual analysis of what might have been had the IC not become involved. History cannot be rewritten, they argue, especially when the subject is war. Litigation will neither win nor end the war, but the development of law and legal processes can contribute to less violence and the peaceful resolution of disputes.

Laurence Helfer and Clare Ryan's contribution "LGBT Rights as MegaPolitics: Litigating Before the ECtHR" examines the evolution of lesbian and gay rights litigation before the ECtHR. ${ }^{73}$ Using new empirical data, they show that the rights of sexual minorities have increasingly been politicized in recent years, and that this politicization is likely to be a feature of future ECtHR cases. Although most of the early controversies involving LGBT rights have become settled in many European countries and are thus no longer mega-political, Helfer and Ryan show how both old and new LGBT right controversies have emerged as mega-political issues in other European countries and before the ECtHR. The authors suggest that recent expansions of ECtHR case law, particularly in the area of same-sex families and asylum, are likely to further politicize LGBT rights litigation before the Strasbourg Court. They provide concrete examples of how the combination of deep social cleavages over LGBT rights in some member states and sovereignty driven politics have fueled the re-politicization of LGBT rights as a mega-political issue-yet only for some countries and with respect to some issues. The mega-politics of LGBT rights is, in other words, highly variable across Europe and with respect to the specific issue involved, so that one increasingly finds different states pitched against each other on these issues.

James Thuo Gathii and Olabisi Akinkube's article "Judicialization of Election Disputes in Africa's International Courts" explores the practice of candidates disputing electoral outcomes in front of regional ICs, even when the IC's jurisdiction for doing so is questionable or non-existent ${ }^{74}$ Litigants turn to ICs because domestic courts tend to ratify the election of incumbents, contributing to the "hegemonic preservation of incumbents." The cases they examine were sometimes adjudicated domestically, sometimes internationally, and sometimes in both venues. The authors are mostly interested in why litigants chose to judicialize the dispute. While the plaintiffs sometimes win legal victories that validate some of their arguments, they do not manage to reverse the electoral outcome. Litigants pursue cases, knowing they will lose, because doing so draws domestic and international attention to their complaints. Given that elections will reoccur, the goal is to draw greater scrutiny for the next election. As the elections are nationally validated, and IC rulings in these cases are generally ignored, the

73. Helfer \& Ryan, supra note 27.

74. Gathii \& Akinkugbe, supra note 25. 
legal reviews are not politically disruptive. Whether the additional scrutiny proves helpful is beyond the scope of the analysis, but the authors observe an emboldening of national court rulings to the point that important national elections were eventually overturned because of election irregularities.

Salvatore Caserta and Pola Cebulak in "Territorial Disputes by Proxy: The Indirect Involvement of International Courts in the Megapolitics of Territory" examines an obvious candidate for mega-political disputes: contested delineations of territory between states. ${ }^{75}$ The authors focus on how these territorial disputes sometimes reach ICs indirectly. More specifically, the article focuses on how regional courts set up to mainly adjudicate economic or human rights matters have increasingly been faced with such indirect territorial disputes. Since these regional courts have compulsory jurisdiction and allow private litigants access, they have created the pathway that different segments of litigants can use to contest territorial claims. Focusing on territorial cases before the Central American Court of Justice, CJEU and the ECtHR, the authors explore how these cases, and the discussion of these cases, is different from the literature on the ICJ's inter-state adjudication of territorial disputes. ICJ cases are generally consensual, and studies find that judicial intervention can help find peaceful resolution to conflicts. The lack of state consent for regional territorial dispute resolution by proxy contributes to more mixed results. In some instances, the intervention of regional judges has exacerbated the underlying inter-state conflict, while in others, regional courts have contributed to stabilizing the conflict and reframing public discourse from being centered on national interest to focusing on individual rights.

Hélène Ruiz Fabri and Edoardo Stoppioni's article "Jus Cogens Before International Courts: The Mega-Political Side of the Story" considers how the legal category of jus cogens generates inter-state conflicts. ${ }^{76}$ While jus cogens is generally understood as a set of fundamental and overriding principles of international law that provide peremptory norms for the international system, the substantive contents of jus cogens norms and their precise value as legal sources are deeply contested. This contest over jus cogens is largely driven by sovereignty claims. This contested category of international law was originally framed as a dispute over Western conceptions of international law against nonaligned and socialist states at the advent of decolonization. More recently, however, Third World approaches to international law (TWAIL) have invested in jus cogens as an emancipatory legal tool against the continuous Western dominance of international law. The authors show how this conflict remains unresolved in international law and that international judges continue to oscillate between a conservative and a progressive stance on jus cogens. Using a more normative TWAIL perspective, the authors argue that jus cogens offers an overlooked procedural potential, and particularly for those who have been reduced to subalterns of the international system.

75. Caserta \& Cebulak, supra note 21.

76. Ruiz Fabri \& Stoppioni, supra note 38. 
Karen J. Alter and Mikael Rask Madsen's conclusion to this special issue, "Beyond Backlash: The Consequences of Adjudicating Mega-Politics," examines the implications of adjudicating mega-politics for politics, for society, for the case at hand, and for the ICs involved. ${ }^{77}$ The authors draw on the findings of the special issue contributions, identifying the many strategies that ICs use to rule on the issue without inciting a political backlash. The conclusion also develops further the claim that adjudicating mega-political disputes need not be democracy undermining. The analysis ends up questioning whether society should be worried about ICs adjudicating mega-political disputes. The cautiously salutary findings do not mean that all involved should welcome more adjudication of mega-political disputes. It is always better for stakeholders to resolve their disputes themselves, so long as minority and vulnerable individuals and groups are not thrown under the bus in the process. These findings do, however, mean that the international adjudication of mega-politics, while deeply frustrating for political leaders who would prefer to ignore international law, is perhaps not something that should be avoided wherever possible. Circling back to Ran Hirschl's concern about juristocracy, the overall finding is that international judicial review need not contribute to juristocracy. Instead, international legal review of mega-political cases may be a limited but nonetheless consequential fail-safe against the alternative of unfettered and unquestioned actions and interpretations of international law, rendering international law a rule-by-law tool of heads of state.

77. Karen J. Alter \& Mikael Rask Madsen, Beyond Backlash: The Consequences of Adjudicating Mega-Politics, 84 LAW \& CONTEMP. PROBS. No. 4, 2021, at 219. 